\title{
FLEET DYNAMICS: ANALYSIS ON FACTORS PERSUADING FLEET PROCUREMENT
}

\author{
${ }^{1}$ Andrew Franklin Prince \\ ${ }^{2}$ Reuban Jacob
}

\begin{abstract}
Fleet sale customers represent the business entities that are capable of purchasing cars in a mass volume. Now-a-days series of competition is prevailing in the market for fleet as it brings high score on sales target. In this situation, it is imperative to know the key drives and benefits which attract the fleet customers on the basis of segment and fuel type. The introduction of new products in the product line and the different fuel type such as CNG(Compressed Natural Gas) has brought down new fervor in the fleet market. The key drives and benefits of fleet customers also enlighten the researchers to explore various aspects in fleet market.
\end{abstract}

Key Words : Fleet, key drives, Segments (Hatchback, Entry Level Sedan, Sedan, SUV / big MUV and Small MUV), Fuel type ( CNG,LPG ,Electric ,Diesel , Petrol).

\section{Introduction :}

Fleet sales symbolises a bulk purchase made by a business entity; personal or organisational. A bulk order for vehicles by an organization or respected groups increases the sales range for the automobile companies at one shot rather than targeting individual customers. This measure also shoots up the profit at a high range, the reason for which companies concentrate on fleet management operations foremost these days.

On another hand Government and corporate prefer better vehicles for their employees at executive and managerial level. The benefit obtained from a bulk purchase will be an added advantage for the organizations to boost the morale of employees by giving them sophisticated transportation. Nowa-days this measure has become a retention tool to add status to employees. Therefore the fleet suppliers target the corporate giants and government, alluring them for a bulk/fleet purchase. Taxi, Rental and Leasing companies are also benefited out of this. Single purchase of cars will not gain much benefit, but going for a bulk purchase will stimulate the bargaining power as well. The additional values or benefits are thrown up to the

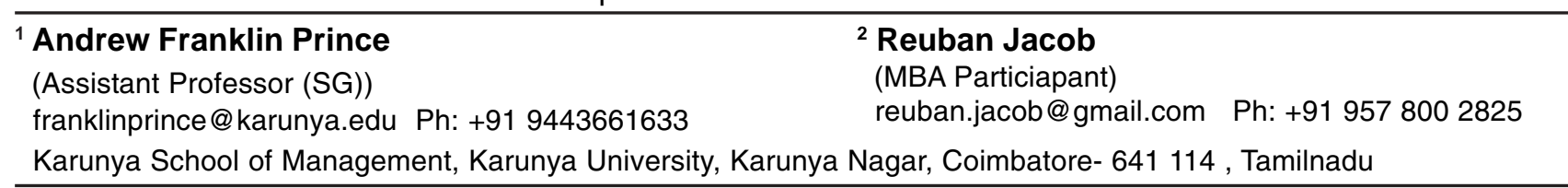

fleet customers to pull them towards the company. Key drives may or may not play a role in fleet market. A serious of competition is prevailing in the market fớrfotleet purchase.

A the demand for the vehicle based on category (ie; seghents as Hatchback, sedan, etc) could depend upon the customer type. The fuel preferred for the fleet vehicles could also change according to the fleet Customer type. This study makes a maiden attempt towards analyzing the share of fuel type preferred by dealers based on the customer's perspective. It also studies the fuel type preference of the fleet customers to determine the fleet market demand. The key drives and the benefits expected from the fleet sales by the consumer is also been analyzed in the study to find out the factors which are important for fleet sales and purchase.

\section{Statement of problem :}

Fleet sales play a vital role in the market, the values given to the fleet customers are crucial for the customer retention in the sturdy market. It is important to know what value or benefits are being taken up by the customers. And it's also crucial to know the key drives which are making the special breed of customers called fleet customers to make a purchase. 
Unlike the normal customers, fleet customer's preferences will be different in many ways. The preference for segments will be unique by the fleet customers. Similarly different fuel type will be preferred by the customers for different segments or vehicle category. These aspects are essential to be analyzed for understanding the fleet market. Thus the problem is to identify the fuel preference for fleet on the basis of segments in the market as well as by the direct fleet customers. The impact of key drives and benefits for the fleet should also be noted under the problem to build a clear idea of the fleet market.

\section{Literature Review}

The aim of the study is to identify, analyze and describe the factors that have an impact on fleet sales. In line with this aim, literature review is done. Lin, Jie Chen, Cynthia Niemeier, Debbie from Transportation; (March 2008), "An analysis on long term emission benefits of a Government vehicle fleet replacement plan in northern Illinois", talks about the efficacy of a fleet replacement program for government in North Illinois, the Forest Preserve of Dupage Country (FPDC) depends upon the vehicle age and gasoline price than any other factor. From Transportation Research Part D: Transport and Environment; (March 2008) "Better performance or lower fuel consumption: Technological development in the Swedish new car fleet 1975-2002". The paper estimates to what extent technology development in the Swedish new car fleet has resulted in lower consumption or has improved service attributes. Haller, Megan Welch, Eric Lin, Jie Fulla, Shelley, again from Transportation Research Part D: Transport and Environment; (May 2007) Economic costs and environmental impacts of aulternative fuel vehicle fleets in local government: An interim assessment of a voluntary ten-year fleet conversion plan" has stated in the paper examining the cost effectiveness and environmental impact of the conversion of a 180 plus vehicle fleet to alternative fuel vehicle technology by a public organization. Finally by summing up, Kevin Nesbitt, Daniel Sperling, from (July 1998) "Myths regarding alternative fuel vehicle demand by light-duty vehicle fleets", states that the study formulated by the information collected from focus group sessions, one-on-one interviews with fleet operators and two part survey. Large number of misconceptions by both fleet operators and policy makers that lead to distorted expectations and ineffective policies regarding the purchase and use of fleet.

\section{Objective of study}

1. To study the Fuel demand for fleet on the basis of the fuel type ( CNG,LPG ,Electric ,Diesel, Petrol) and the segment to which they have to (Hatchback, Entry Level Sedan, Sedan, SUV / big MUV and Small MUV).

2. To study the scope of self drive to make a potential fleet purchase in the market.

\section{Methodology}

The research used for this study is descriptive in nature and was conducted for a period of three months from October 2010 to December 2010.

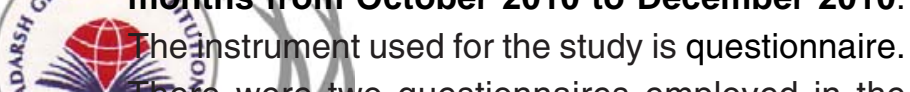
fors
1 For dealers, geographical area of 10 major cities
IE $A$ has been targeted. And the survey for consumer has been targeted on fleet customers.

\section{Sampling}

The Stratified Random Sampling Technique was employed during the data collection for dealers. The 10 major cities in India ie; Chennai, Bangalore, Delhi, Cochin, Ludhiana, Hyderabad, Mumbai, Pune, Jaipur, Guwahati have been geographically targeted for the dealers of Hyundai, Tata, Mahindra and Mahindra, Maruti Suzuki, Volkswagen and Nissan. Data has been collected on a ratio of $1 / 4^{\text {th }}$ from each competitor company's dealers in each locality to understand the fleet competition Table - 1. Totally out of targeted 173 sample population 73 samples has been taken to analyze dealers. Only the main branch dealers has been considered for the study, sister branches are eliminated. On another hand, Simple Random sampling technique was employed during the data collection of fleet customers. The 
sample constitutes of 4 types of consumers. They are: Government, Corporate, Rental and Leasing companies. This comes to a sample size of $\mathbf{5 2}$ consumers

\section{Limitation of the Study}

The study carries some limitations as well. To make the research feasible certain areas has been narrowed down in the research; which are highlighted below.

- The survey for dealers has been carried out only in 10 major towns in India.

- Fleet customers has been targeted randomly, and not by the exact population prevailing in the market.

- The research work is done for a limited period of three months.

\section{Analysis and Discussion}

\section{Company demanded for fleet}

The companies entertaining fleet sales are in $a$ scurry to get the maximum sales target on the board. The customer preference for the company which they are giving more importance in their future purchase is very vital. Table 2 shows that the preference of company for fleet purchase by the customers.

It is seen from Table 2 that Ford is topping the cards with $19.64 \%$, Tata, Maruti Suzuki and Toyota has been preferred second by the customers with $16 \%$. Tata and Toyota might be highly scored due to the MUV(Multi Utility Vehicle) performance by the each company. Rental and the Government customers has to be the demand pullers for those company. Volkswagen secures the third spot with $14.29 \%$ which is considered to be a good performance by the company, taking into consideration that the company is relatively new to the Indian market. Both Maruti Suzuki and Volkswagen is assumed to give much competition for Ford in the immediate future as they are competing for the similar segments in the market. Tata and Toyota will not be considered as a competition for Ford as the company is shot of MUV in the market to compete with the two companies.

\section{Customer Satisfaction}

It is highly important for the companies to keep the customers satisfied as always. More than the regular customers, fleet customers will be demanding more. Table 3 shows the customers view on which company holds they satisfied by giving more importance to fleet customers.

It is understood from Table 3 that, Ford gives high preference to fleet customers. In other words, Ford's customers are satisfied with the company's effort in keeping them in high spirits compared with the competitors. It could be assumed that Table 2 and 3 are having a relevant relation on Ford's aspect. It could be interpreted as, due to high preference given by the company for the fleet customers, the company is demanded by the customers for the future fleet purchase. Again Maruti Suzuki and Tata is one step behind Ford by scoring $21 \%$ each, this clearly shows that, these companies are giving tough competition to Ford in the fleet market.

\section{UP OF IN}

Demand on fuel per segment

$=\overline{0}$

The sfyel type in market is listed as Petrol, Diesel, NGaLPE (Liquefied Petroleum Gas) and CNG (Compressed Natural Gas). The CNG has been a new entry into the Indian market, the gas project which is considered to be environment friendly. The demand for the gas has to be analysed on fleet market as well. Table 4 shows the demand result of four different type of fleet customers (rental, leasing, Government and corporate) on three fuel types. The responses have been positively responded but LPG has not been preferred even by a single customer and it has been eliminated from the table list.

Table 4 starts with the Petrol; Hatchback has been preferred more on the Petrol with $43 \%$ and the Entry Level Sedan with $34 \%$ and Sedan with $21 \%$ stands second and third respectively. This demand could be pulled by the corporate customers. SUV is only demanded for $2 \%$ and under MUV not even a single response has been noted under Petrol fuel category.

Diesel has shown a top score in Entry Level Sedan with $30 \%$, followed by Hatchback with $24 \%$ demand. As expected Small MUV carries $22 \%$ which is a 
relevant demand in the market. This pattern of demand by the rental and Government customers who are highly in demand for MUVs but are one step behind the Sedan with $17 \%$. Thus it could be inferred that the sedan type is highly proffered in the fleet market. SUV or big MUV has also been demanded for fleet under Diesel with $7 \%$ in the market.

Compressed Natural Gas is considered to be the fresh influx in the market has got low response; the reason is that the gas stations have been installed in the main metros only while the study has been undertaken. However the hatchback has been demanded more among CNG fuel category with $19 \%$ followed by entry level sedan with $8 \%$ and Sedan on 3.8 in the fleet market. The entry level sedan could be counted with the Maruti Suzuki's SX4 which is been highlighted by the company for CNG.

Table 5 and Chart 1 shows the overall percentage of the fuel preferred by the fleet customers. The result has been found by summing the response received in each fuel type. This comprises all the segments on discussion. Table 5 and Chart 1 resemble the same result. Diesel has been highly demanded by the fleet customers as anticipated. The $25 \%$ on Petrol demand might be the demand put by the corporate customers. CNG has been demanded on $8 \%$ which shows a relative good demand, taken into consideration that the gas is still in its baby steps. The lack of awareness about the gas also could be the reason. Once the gas stations are installed in major cities the demand is expected to shoot up sky high as the starting phase result is appreciable. Mean time Table 5 shows that LPG has not preferred by any fleet customer, which shows a negative demand signal for the gas in the market for fleet.

Table 6 and Chart 2 highlights the combined figures of fuel demand on each segments in the entire market. The data is been derived from the dealer survey, understanding how the dealers are been selling to the fleet customers which is depicting a sketch of the fleet market. Thus the demand thrown before each other competitors could be put into one table and chart.
It is seen from the Table 6 that Hatchback segment is highly preferred on Petrol with $52 \%$ and Diesel also stands close to it with 45\%, LPG and CNG has $7 \%$ demand. Entry level sedan shows a remarkable $67 \%$ demand on Diesel which is the highest in any of the category. Followed by Petrol with $22 \%$ for the segment, the demand for gas types are rather low. Sedan secures $4 \%$ demand on diesel and $3 \%$ on petrol. SUV or big MUV shows 3 $\%$ demand on diesel. Small MUV has a relevant score with $36 \%$ demand in the market, this could be pulled majorly by Government and rental customers.

\section{Key drives on a fleet purchase}

The key drives that influence the purchase of an automobile are to be considered vital in the industry. The customers are eager in grabbing the maximum benefits out of fleet purchase but still there are certailn key drives which make the purchase more aceurate. Table 7 depicts that performance has Hee ranked heavily by most of the respondents and nold the rank one position. Service quality stands VGALAext for fleet, price is coming on the third rank for fleet purchase. Offers and gifts could also be taken into consideration as they are standing fourth and sixth positions. Dealership has been ranked low but the service is been rated on second so the importance of the dealership should not be underestimated.

\section{Benefits expected by customers}

The benefits will be thrown to customers by every company, but it's important to know what benefit customer prefers more and are vital for them. Data has been consolidated to get a mean between 1-5, Mean is derived as using the formula " $x / n$, in which ' $n$ ' being the number or respondents.

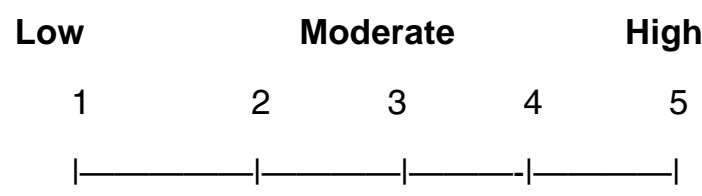

The point 1 being the lowest, point 5 indicated the highest and point 3 stand for moderate. 
Table 8 represents that the extended warranty has been rated almost on top by all customers except leasing which goes to a moderate mean of 3.67. Special service schemes have been rated even with a good rate on the table. Price discount is been asked by the customers except Government showing a mere moderate mean. May be this is due to the DGS\&D's ( Director General Supplies and Disposal) rate contract which facilitate the government to make purchase on particular items which is listed in the contract. As price is also coated in the rate contract there is no point from government side to make a bargaining, that could be the reason for the moderate response for price discounts by the Government. Offers and gifts has been enquired for intensively by corporate customers while other customers are casual towards the same. Buy back guarantee has been put up with a good response as most of the customers rated above 4 except Government. This could be due to, the used old vehicles will be shifted to other offices in the rural areas or to the sub offices. Though none have turned down any benefit, they don't grudge any benefit that comes their way.

\section{Conclusion}

The potential of the fleet market has been analyzed through the study. The demand by the fleet customers is always sky scraping. Efforts have been 971 to 2011 employed to know the changing nature of fleet customer's preference on segments or vehicle category. The key drives and benefits facilitates the fleet customers to make a bulk/fleet purchase. The fuel preference has revealed the importance of diesel fuel in fleet market. But the revelation of CNG's growing demand even in the early stages has brought about curiosity, in spite of being a gas fuel the fleet market is demanding for it. Ford has been rated as the toughest competitor in the fleet market as their priority to fleet customers has also been realized. Sedan segment in fleet is also put up as an eye-opener for the fleet market. The growing importance of fleet resulting in companies trying to impress or satisfy the customers, turns out to be a highly challenging job. Nevertheless this study threw light on the fleet market where the companies could be benefited.

\section{References}

- Authors: Pachon, Julian lakovou, Eleftherios Ip, Chi Aboudi, Ronny. IIE Transactions; September 2003, Vol. 35 Issue: Number 9 p907-916, 10p ISSN: 0740817X

- Authors: Lin, Jie Chen, Cynthia Niemeier, Debbie. Transportation; March 2008, Vol. 35 Issue: Number 2 p219-235, 17p ISSN: 00494488; 15729435

- Authors: Ryan, Lisa Ferreira, Susana Convery, Frank. Energy Economics; May 2009, Vol. 31 Issue: Number 3 p365-374, $10 p$

- Authors: Haller, Megan Welch, Eric Lin, Jie Fulla, Shelley. Transportation Research Part D: Transport and Environment; May 2007, Vol. 2 Issue: Number 3 p219-230, 12p ISSN: 13619209

Author: Kevin Nesbitt, Daniel Sperling. Transportation Research Part D: Transport and Environment, Volume 3, Issue 4, July 1998, Pages 259-269 


\section{Annexure}

TABLES

Table 1 : Dealer sample

\begin{tabular}{|c|c|c|c|c|c|c|c|c|c|c|c|}
\hline $\begin{array}{c}\text { Company } \\
\text { Dealers }\end{array}$ & Chennai & $\begin{array}{c}\text { Banga- } \\
\text { lore }\end{array}$ & Delhi & Cochin & Ludhiana & $\begin{array}{c}\text { Hydera- } \\
\text { bad }\end{array}$ & Mumbai & Pune & Jaipur & $\begin{array}{c}\text { Guwa- } \\
\text { hati }\end{array}$ & Total \\
\hline Hyundai & $3 / 6$ & $1 / 2$ & $1 / 3$ & $2 / 5$ & $1 / 3$ & $1 / 3$ & $2 / 6$ & $2 / 3$ & $1 / 3$ & $1 / 2$ & $15 / 36$ \\
\hline Mahindra & $3 / 5$ & $1 / 4$ & $2 / 5$ & $1 / 2$ & $1 / 2$ & $1 / 3$ & $2 / 5$ & $1 / 2$ & $1 / 3$ & $1 / 2$ & $14 / 33$ \\
\hline Tata & $1 / 4$ & rejected & $2 / 5$ & rejected & $1 / 2$ & $1 / 4$ & $3 / 4$ & $2 / 3$ & $1 / 2$ & $2 / 3$ & $13 / 27$ \\
\hline VW & $2 / 2$ & $2 / 3$ & $2 / 3$ & $1 / 2$ & $1 / 1$ & $1 / 1$ & $2 / 3$ & $1 / 1$ & $1 / 1$ & $\begin{array}{c}\text { No } \\
\text { Dealers }\end{array}$ & $13 / 17$ \\
\hline Maruti & $2 / 6$ & $1 / 7$ & $1 / 9$ & $1 / 3$ & $1 / 5$ & $1 / 4$ & $1 / 5$ & $1 / 7$ & $1 / 4$ & $1 / 3$ & $11 / 53$ \\
\hline Nissan & $1 / 1$ & $1 / 1$ & $1 / 1$ & $1 / 1$ & $\begin{array}{c}\text { No } \\
\text { Dealers }\end{array}$ & $1 / 1$ & $\begin{array}{c}\text { No } \\
\text { Dealers }\end{array}$ & $1 / 1$ & $1 / 1$ & $\begin{array}{c}\text { No } \\
\text { Dealers }\end{array}$ & $7 / 7$ \\
\hline TOTAL & $\mathbf{1 2 / 2 4}$ & $\mathbf{6} / 17$ & $\mathbf{9} / \mathbf{2 6}$ & $\mathbf{6} / \mathbf{1 3}$ & $\mathbf{5} / \mathbf{1 3}$ & $\mathbf{6 / 1 6}$ & $\mathbf{1 0 / 2 3}$ & $\mathbf{8} / \mathbf{1 7}$ & $\mathbf{6 / 1 4}$ & $\mathbf{5} / 10$ & $\mathbf{7 3 / 1 7 3}$ \\
\hline
\end{tabular}

Table 2 : Company preferred by fleetconsumers for future purchase

\begin{tabular}{|l|c|c|}
\hline Company & Frequency & Percentage \\
\hline Maruti Suzuki & 971 201 & 16.07 \\
\hline Tata & 9 & 16.07 \\
\hline Hyundai & 3 & 5.36 \\
\hline Ford & 11 & 19.64 \\
\hline Volkswagen & 8 & 14.29 \\
\hline Nissan & 0 & 0.00 \\
\hline M \& M & 6 & 10.71 \\
\hline Toyota & 9 & 16.07 \\
\hline Honda & 1 & 1.79 \\
\hline Others & 0 & 0.00 \\
\hline
\end{tabular}


Table 3: Company giving priority to Fleet customers

\begin{tabular}{|l|c|c|}
\hline Company & Frequency & Percentage \\
\hline Maruti Suzuki & 15 & 21.43 \\
\hline Tata & 15 & 21.43 \\
\hline Hyundai & 4 & 5.71 \\
\hline Ford & 20 & 28.57 \\
\hline Volkswagen & 4 & 5.71 \\
\hline Nissan & 0 & 0.00 \\
\hline M \& M & 7 & 10.00 \\
\hline Toyota & 5 & 7.41 \\
\hline Honda & 0 & 0.00 \\
\hline Others & 0 & 0.00 \\
\hline
\end{tabular}

Table 4 : Fuel demand on each Segment

\begin{tabular}{|c|c|c|c|c|c|c|}
\hline \multirow{2}{*}{ Segments } & \multicolumn{2}{|c|}{ Petrol } & & sel & \multicolumn{2}{|c|}{ CNG } \\
\hline & Tota & & & ercentage & Total & Percentage \\
\hline Hatchback & 20 & 425 & $A+30 \%$ & 23.81 & 10 & 19.2 \\
\hline Entry Level Sedan & 16 & 34.04 & $\triangle 38 \mathrm{~S}$ & 30.16 & 4 & 7.7 \\
\hline Sedan & 10 & $21.28 / 1$ & to 2101 & 16.67 & 2 & 3.8 \\
\hline SUV / big MUV & 1 & 2.13 & 9 & 7.14 & 0 & 0.0 \\
\hline Small MUV & 0 & 0.00 & 28 & 22.22 & 0 & 0.0 \\
\hline
\end{tabular}

Table 5 : Over all Fuel Preferred

\begin{tabular}{|c|c|c|}
\hline Fuel & Frequency & Percentage \\
\hline Petrol & 47 & 24.87 \\
\hline Diesel & 126 & 66.67 \\
\hline CNG & 16 & 8.47 \\
\hline LPG & 0 & 0.00 \\
\hline
\end{tabular}


Table 6 : Combined analysis of fuel demand on each segment in the market

\begin{tabular}{|c|c|c|c|c|c|c|c|c|c|c|}
\hline & \multicolumn{2}{|c|}{ Hatchback } & \multicolumn{2}{|c|}{ Entry Level Sedan } & \multicolumn{2}{c|}{ Sedan } & \multicolumn{2}{c|}{ SUV / big MUV } & \multicolumn{2}{c|}{ Small MUV } \\
\cline { 2 - 11 } & $\begin{array}{c}\text { Frequ- } \\
\text { ency }\end{array}$ & $\begin{array}{c}\text { Percen- } \\
\text { tage }\end{array}$ & $\begin{array}{c}\text { Frequ- } \\
\text { ency }\end{array}$ & $\begin{array}{c}\text { Percen- } \\
\text { tage }\end{array}$ & $\begin{array}{c}\text { Frequ- } \\
\text { ency }\end{array}$ & $\begin{array}{c}\text { Percen- } \\
\text { tage }\end{array}$ & $\begin{array}{c}\text { Frequ- } \\
\text { ency }\end{array}$ & $\begin{array}{c}\text { Percen- } \\
\text { tage }\end{array}$ & $\begin{array}{c}\text { Frequ- } \\
\text { ency }\end{array}$ & $\begin{array}{c}\text { Percen- } \\
\text { tage }\end{array}$ \\
\hline Petrol & 38 & 52.05 & 16 & 21.92 & 2 & 2.74 & 0 & 0.00 & 1 & 1.37 \\
\hline Diesel & 33 & 45.21 & 49 & 67.12 & 3 & 4.11 & 2 & 2.74 & 26 & 35.62 \\
\hline CNG & 5 & 6.85 & 1 & 1.37 & 0 & 0.00 & 0 & 0.00 & 0 & 0.00 \\
\hline LPG & 5 & 6.85 & 1 & 1.37 & 0 & 0.00 & 0 & 0.00 & 0 & 0.00 \\
\hline
\end{tabular}

Table 7 : Key Drives.

\begin{tabular}{|c|c|}
\hline Key drives & Rank \\
\hline Performance & 1 \\
\hline Service Quality & 2. \\
\hline Price & 3 \\
\hline Attractive Packages, (Offers) & 4 \\
\hline Approachability for Service & 5 \\
\hline YEAR & $S$ \\
\hline 1971 to 2 & 117 \\
\hline Dealership & 8 \\
\hline
\end{tabular}

Table 8: Benefits

\begin{tabular}{|l|l|l|l|l|}
\hline Benefits & Corporate & Leasing & Rental & Govt \\
\hline Extended warranty & 4.28 & 3.67 & 4.14 & 4.53 \\
\hline Special Service schemes & 4.57 & 4 & 4.57 & 4.4 \\
\hline Price discounts & 4.78 & 4.44 & 4.78 & 3 \\
\hline Offer packs / Gifts & 4.35 & 3.44 & 3 & 3.4 \\
\hline Buy back Guarantee & 4 & 4.11 & 4.14 & 3.47 \\
\hline
\end{tabular}




\section{CHARTS}

Chart 1: Over all Fuel Preferred

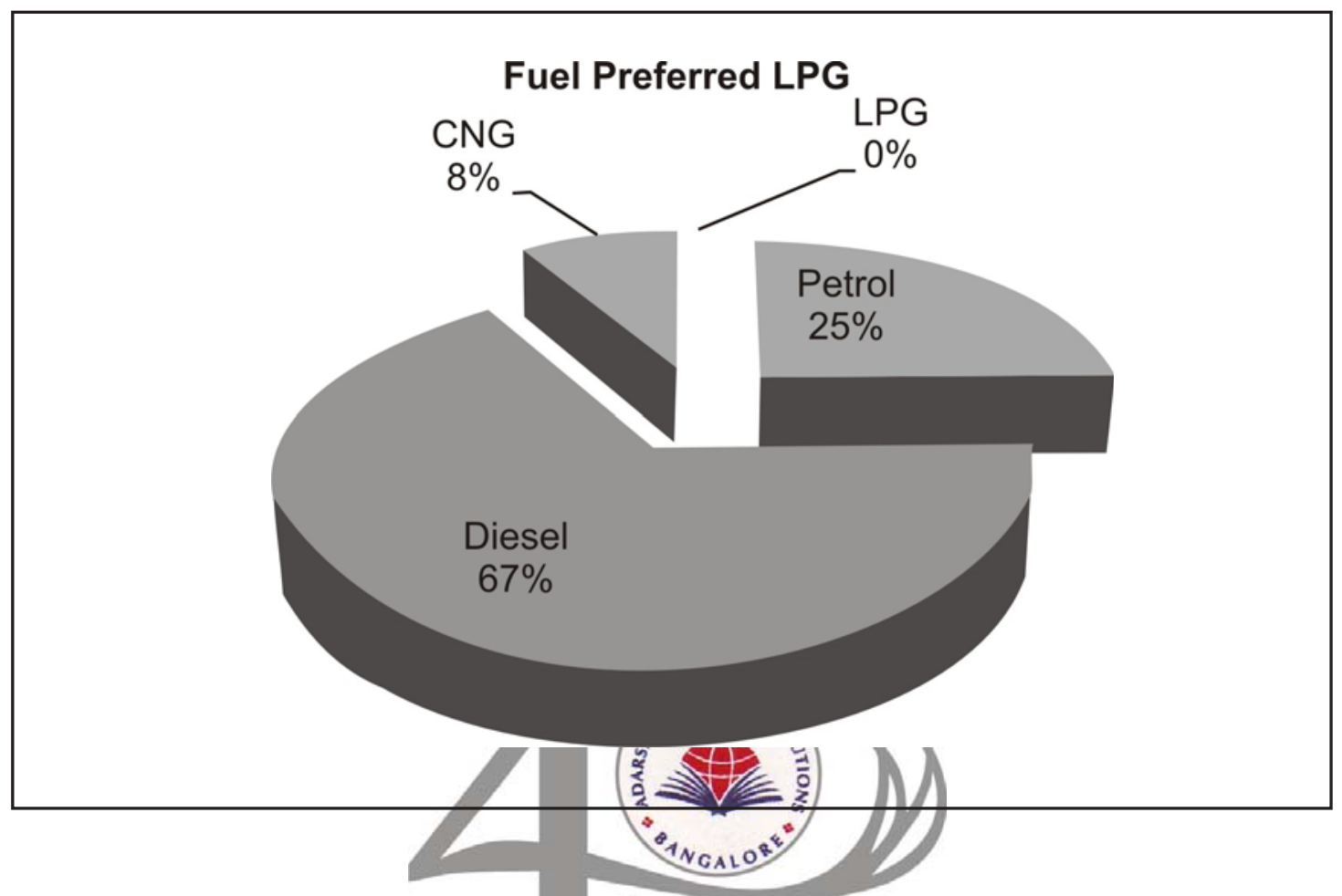

Chart 2: Combined analysis of fuel demand on each segment

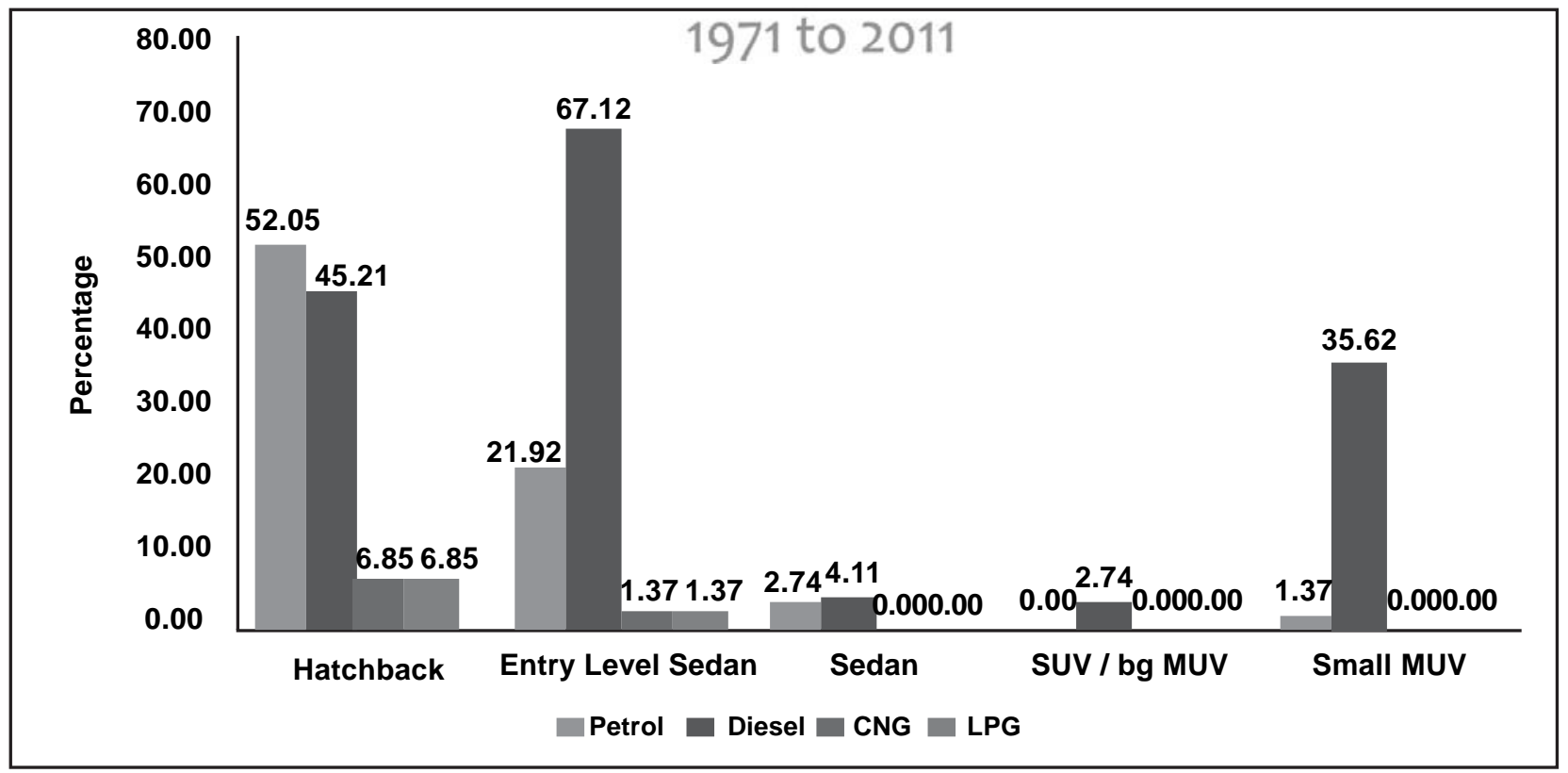

